\title{
Pengembangan Materi Layanan Informasi Studi Lanjut Berbantuan Media Sosial Instagram untuk Perencanaan Karier Siswa SMA
}

\author{
Via Puspita Lindasari*, Muslihati, Henny Indreswari \\ Universitas Negeri Malang, Jl. Semarang No. 5 Malang, Jawa Timur, Indonesia \\ *Penulis korespondensi, Surel: viapuspita24@gmail.com
}

Paper received: 3-5-2021; revised: 24-5-2021; accepted: 28-5-2021

\begin{abstract}
This research aims to produce further study information service materials assisted by Instagram social media for high school student career planning in an effort to facilitate information on secondary school students of SMAN 1 Durenan, Trenggalek. The research used is research and development using the Reach and Development model. The research steps carried out began with knowing the problem, carrying out need assessment, formulating objectives, designing the initial product, expert testing (material experts \& media experts) and user testing (counselors), revisions of the results of expert testing and user testing, after design and material revisions ready to use. Data collection was carried out twice, namely pre-development data collection and post-development data collection. Pre-development data collection was carried out by interviewing counselors and students via WhatsApp, as well as distributing statement forms to students. The results show that students at SMA Negeri 1 Durenan have not been able to plan their secondary school well so that further study information services need to be provided in order to find suitable alternative secondary schools. Therefore, researchers developed further study information service materials assisted by Instagram social media. Furthermore, post-development data collection is by conducting validity tests on media experts, material experts and testing prospective users (counselors). The results showed that the advanced study service material products developed were very acceptable and could be used by students in exploring secondary schools.
\end{abstract}

Keywords: secondary school information service; social media Instagram; career planning

\begin{abstract}
Abstrak
Penelitian ini bertujuan menghasilkan materi layanan informasi studi lanjut berbantuan media sosial instagram untuk perencanaan karier siswa SMA dalam upaya memfasilitasi informasi sekolah lanjutan siswa SMAN 1 Durenan, Trenggalek. Penelitian yang digunakan yaitu penelitian dan pengembangan dengan menggunakan model Reach and Development. Langkah penelitian yang dilakukan diawali dengan mengetahui masalah, melakukan need assessment, merumuskan tujuan, mendesain produk awal, uji ahli (ahli materi \& ahli media) dan uji pengguna (konselor), revisi dari hasil uji ahli dan uji pengguna, setelah revisi desain dan materi siap digunakan. Pengumpulan data dilakukan sebanyak dua kali yakni pengumpulan data pra pengembangan dan pengumpulan data pasca pengembangan. Pengumpulan data pra pengembangan dilakukan dengan wawancara kepada konselor dan siswa, serta penyebaran form pernyataan kepada siswa. Hasil menunjukkan bahwa siswa di SMA Negeri 1 Durenan belum mampu merencanakan sekolah lanjutan mereka dengan baik sehingga perlu diberikan layanan informasi studi lanjut agar dapat menemukan alternatif sekolah lanjutan yang sesuai. Oleh karena itu peneliti mengembangkan materi layanan informasi studi lanjut berbantuan media sosial instagram. Selanjutnya pengumpulan data pasca pengembangan yaitu dengan cara melakukan uji validitas kepada ahli media, ahli materi dan uji calon pengguna (konselor). Hasil menunjukkan bahwa produk materi layanan studi lanjut yang dikembangan sangat berterima dan dapat digunakan oleh siswa dalam mengeksplorasi sekolah lanjutan.
\end{abstract}

Kata kunci: Layanan informasi studi lanjut; media sosial instagram; perencanaan karier 


\section{Pendahuluan}

Keberhasilan dalam menempuh karier merupakan suatu pencapaian berharga bagi seseorang. Perencanaan karier menjadi peran penting dalam mencapai keberhasilan tersebut. Dalam proses perencanaan karier tidak hanya sekedar memilih bidang atau profesi tertentu, akan tetapi dengan mempertimbangkan kelemahan dan kelebihan yang dimiliki seseorang, agar hasil yang diperoleh memuaskan. Asumsi ini diperkuat oleh pendapat Nathan \& Hill (dalam Tumanggor 2018) bahwa karir merupakan suatu proses yang berlangsung seumur hidup, dipilih, dan ditentukan untuk melalui suatu proses dimana tidak hanya mempertimbangkan kekuatan dan kelemahan personal individu, namun memfokuskan pada aspek-aspek ekstrinsik dari kepuasaan dalam memilih pekerjaan seperti uang, status, dan kondisi kerja.

Sekolah Menengah Atas (SMA) merupakan masa transisi dari remaja ke dewasa, dimana mereka harus sudah memiliki pandangan akan kemana setelah lulus SMA. Teori perkembangan karier Super (Sukardi 1994) siswa SMA masuk pada tugas perkembangan vokasional kristalisasi yakni suatu periode proses kognitif merumuskan suatu tujuan karier yang bersifat umum melalui sumber kesadaran, kemungkinan, minat, nilai-nilai, dan perencanaan untuk memilih pekerjaan yang disukai. Keahlian dalam membuat keputusan merupakan tujuan dalam perencanaan karier yang harus dilalui setiap siswa. Siswa yang telah menempuh jenjang studi SMA maka siswa tersebut akan melanjutkan ke jenjang yang lebih tinggi atau sekolah lanjutan yang mereka kehendaki. Menurut Sutikna (1998) studi lanjut merupakan "pendidikan sambungan atau lanjutan setelah tamat dari pendidikan yang saat ini ditempuh". Siswa yang telah menyelesaikan masa studi di SMA bebas memilih sekolah lanjutan yang mereka kehendaki.

Namun data faktual yang diperoleh dari hasil wawancara pada siswa kelas X, XI jurusan Ilmu Pengetahuan Sosial di sekolah tempat penelitian, sekitar 75\% dari mereka mengalami hambatan yang sama diantaranya yaitu: belum bisa menentukan kelanjutan studi karena tidak tahu potensi yang dimiliki, belum memiliki pandangan yang jelas tentang kelanjutan studi setelah lulus 3 sekolah, merasa bimbang karena memiliki 2 pilihan studi, memilih jurusan berdasarkan ajakan teman, lebih memilih bergantung pada orangtua tanpa mempertimbangkan kelebihan dan kelemahan serta kurangnya informasi studi lanjut yang mereka dapat.

Berdasarkan data tersebut, menunjukkan bahwa beberapa siswa di SMA Negeri 1 Durenan membuat pilihan studi lanjut, tanpa mempertimbangkan kemampuan diri mereka. Hambatan lain yang dialami siswa yakni kurangnya informasi yang tidak bisa menunjang belajar siswa untuk mengeksplor studi lanjutan dengan baik. Sulit bagi mereka untuk mendapatkan pengetahuan akan studi lanjutan, ketika lingkungan mereka tidak mendukung.

Merencanakan karier dalam menentukan studi lanjut bukan hanya sekedar memilih atau ikut-ikutan melainkan memilih yang memang sesuai dengan kemampuan diri mereka. Siswa yang mengalami hambatan dalam perencanaan karier, memerlukan pemahaman yang diperoleh melalui informasi mengenai studi lanjut digunakan sebagai acuan dalam meningkatkan pengetahuan dan wawasan, meningkatkan belajar, mengembangkan keterampilan, serta mengevaluasi kesalahan dalam mengambil keputusan. Menurut Prayitno (2012:50), layanan informasi berusaha memenuhi kekurangan individu akan informasi yang 
mereka perlukan. Informasi yang diperoleh kemudian diolah dan digunakan oleh individu untuk kepentingan hidup dan perkembangannya.

Pelaksanaan layanan informasi studi lanjut memerlukan sebuah media, sebagai alat penyampaian informasi kepada siswa. Media yang digunakan perlu juga disesuaikan dengan siswa, agar layanan yang disampaikan oleh konselor mampu diterima dengan baik oleh siswa. Seperti yang dipaparkan ABKIN (2007) bahwa adanya media bimbingan dapat meningkatkan optimalisasi pelayanan bimbingan dan konseling.

Penggunaan media yang saat ini sering digunakan dalam pelaksanaan pembelajaran di sekolah adalah internet. Pemanfaatan internet dalam pembelajaran di sekolah antara lain memberikan informasi belajar kepada siswa. Internet menjadi terobosan penting bagi dunia pendidikan saat ini karena pandemi Covid-19, yang membuat diberhentikannya kegiatan belajar tatap muka untuk saat ini. Penggunaan internet yang menarik digunakan dalam penyampaian layanan informasi studi lanjut, salah satunya melalui media sosial Instagram. Melihat instagram banyak digandrungi oleh siswa, maka aplikasi ini dipilih menjadi media penyampaian layanan informasi studi lanjut.

Penelitian ini dikuatkan dengan penelitian terdahulu yakni dalam penelitian Zakkiyah \& Wiryosutomo (2019) yang berjudul Pengembangan Layanan Informasi Studi Lanjut Berbasis Instagram untuk Siswa SMP Negeri 46 Surabaya, memaparkan bahwa 95\% produk layanan informasi studi lanjut yang dikembangkan sangat baik, dan memenuhi kriteria akseptabilitas. Sedangkan menurut Noviyanti (2020) dalam penelitiannya yang berjudul Instagram Social Media As Guidance and Counseling Media Based On Technology memaparkan bahwa media sosial instagram dapat dimanfaatkan oleh konselor sebagai media penunjang program layanan bimbingan dan konseling berbasis teknologi. Berdasarkan pernyataan tersebut, dapat diketahui bahwasanya media sosial instagram memungkinkan digunakan dalam penyampaian berbagai informasi termasuk informasi studi lanjut.

Peneliti mengembangkan materi layanan informasi studi lanjut berbantuan media sosial instagram yang berisikan informasi sekolah lanjutan. Materi yang dikembangkan dan dimuat pada media sosial 9 instagram mampu menghemat waktu siswa dalam mencari informasi tentang studi lanjutan, tanpa harus mendatangi lembaga atau instansi tertentu. Keunggulan pemberian layanan informasi melalui instagram ini adalah, instagram mampu memuat banyak informasi, selain memuat banyak informasi instagram juga mudah untuk diakses, instagram merupakan media sosial yang sering dikunjungi oleh remaja. Poster di desain semenarik mungkin dengan menyesuaikan karakter penerima layanan informasi. Dari hasil need assessment yang diperoleh dapat diketahui bahwa 70\% siswa memerlukan layanan informasi studi lanjut yang dapat diakses melalui media instagram sebagai sumber informasi mereka. Salah satu diantaranya beralasan bahwa media instagram sering ia akses karena mudah dan menyenangkan.

Layanan informasi studi lanjut yang didukung oleh aplikasi instagram ini diharapkan mempermudah siswa dalam mempelajari informasi studi lanjut. Bahan ajar ini juga sesuai dengan layanan dasar bimbingan dan konseling yakni membantu siswa dalam mengembangkan diri, mengetahui informasi bakat dan minat, serta informasi kepribadian mereka. Berdasarkan seluruh uraian diatas yakni pemanfaatan instagram sebagai media penyampaian materi layanan informasi studi lanjut, yang menunjang belajar siswa dalam mengeksplorasi studi lanjutan, dalam rangka membantu siswa merencanakan kariernya, maka 
penelitian ini perlu dilakukan. Peneliti bermaksud mengembangkan materi layanan informasi studi lanjut melalui media sosial instagram dengan nama akun @Explore_studilanjut untuk pelaksanaan layanan informasi studi lanjut, yang dapat digunakan siswa SMA.

\section{Metode}

Penelitian ini menggunakan penelitian dan pengembangan dengan model Reach and Development (R\&D). Menurut Sugiyono (2009) metode penelitian dan pengembangan (R\&D) merupakan metode penelitian yang dipakai untuk menghasilkan produk tertentu, dan menguji keefektifan produk itu. Metode ini dipilih karena peneliti berusaha untuk mengembangkan sebuah layanan informasi studi lanjut berbantuan media sosial instagram yang dapat membantu siswa dalam mengeksplorasi sekolah lanjutan serta membantu konselor dalam melaksanakan bimbingan karier. Peneliti mengambil kelas XI jurusan IPS sebagai subjek penelitian.

Metode penelitian dan pengembangan yang digunakan memiliki 10 langkah, namun prosedur pengembangan ini diadaptasi oleh peneliti dari model penelitian dan pengembangan dari Borg and Gall (1983) menjadi 5 langkah. Langkah penelitian diawali dengan tahap pengumpulan informasi, tahap perencanaan, tahap pengembangan produk awal, tahap uji coba produk awal kepada uji ahli (ahli materi \& ahli media) dan uji pengguna (konselor), revisi dari hasil uji ahli dan uji pengguna, setelah revisi produk siap digunakan.

Pengumpulan data dilakukan sebanyak dua kali yakni pengumpulan data pra pengembangan dan pengumpulan data pasca pengembangan. Pengumpulan data pra pengembangan ini berupa wawancara kepada konselor dan siswa dalam mencari informasi awal tentang media seperti apa yang diinginkan oleh siswa dalam mengeksplorasi studi lanjut. Hasil wawancara digunakan untuk mengetahui media yang digunakan serta bagaimana layanan bimbingan dan konseling di di sekolah, kendala yang dialami oleh siswa dalam mencari informasi, dan kendala yang dialami oleh konselor dalam menyampaikan layanan informasi studi lanjut, perencanaan karier siswa.

Kedua, angket pertanyaan digunakan peneliti untuk mendapatkan informasi dari siswa tentang pemahaman siswa mengenai informasi studi lanjut, pemahaman siswa terhadap potensi yang dimiliki, dan media seperti apa yang ingin digunakan oleh siswa dalam mencari informasi sekolah lanjutan. Hasil dari angket pra pengembangan tersebut akan digunakan untuk mengetahui media apa yang dapat digunakan oleh siswa dalam mengeksplorasi sekolah lanjutan di SMA Negeri 1 Durenan.

Pengumpulan data pasca pengembangan yakni instrumen yang digunakan untuk memperoleh data mengenai kebermanfaatan materi layanan informasi studi lanjut berbantuan media sosial instagram. Instrumen berupa angket uji coba produk. Angket uji coba produk diberikan kepada ahli materi, media dan pengguna untuk melihat kebermanfaatan dari produk, mulai dari isi materi dan desain dari materi layanan informasi studi lanjut. Angket uji coba produk berisikan 4 aspek yakni kegunaan, kemudahan, kemenarikan dan kebermanfaatan. 


\section{Hasil dan Pembahasan}

\subsection{Hasil}

Produk yang dikembangkan dalam penelitian dan pengembangan ini berupa materi layanan informasi studi lanjut berbantuan media sosial instagram, yang didesain poster ringkas untuk siswa SMA. Produk yang dihasilkan telah melalui beberapa tahap, yakni mulai dari desain poster dan penjabaran isi materi. Poster didesain dengan warna putih sebagai warna utama, yang dikombinasikan dengan warna biru dan kuning. Warna putih melambangkan kesederhanaan, warna biru melambangkan komunikatif, sedangkan warna kuning melambangkan optimisme. Poster juga dikombinasikan dengan gambar yang bernuansa gedung perkuliahan, mahasiswa, serta animasi yang menggambarkan studi lanjutan. Teks pada materi yang ditulis dengan size, font dan warna yang mudah untuk dibaca. Pengembang juga menambahkan watermark pada setiap bagian bawah poster untuk memberi identitas pada poster. Desain isi materi pada poster dibuat ringkas, agar pembaca/siswa bisa langsung tertuju pada inti materi. Ukuran poster yang dipilih sebesar 1080 X 1080 pixel, yang menyesuaikan ukuran pada instagram, agar resolusi pada poster tidak rusak. Poster yang telah selesai didesain, selanjutnya akan di upload pada akun instagram @explore_studilanjut.

Pelaksanaan uji coba produk dalam penelitian dan pengembangan materi layanan informasi studi lanjut berbantuan media sosial instagram untuk perencanaan karier siswa SMA, memberikan hasil antara lain:

Analisis hasil dari indeks uji ahli media sebesar 1, maka termasuk dalam kriteria validitas nilai 0,76 - 1,00 sehingga produk dapat dinilai memiliki klasifikasi validitas sangat tepat, sangat bermanfaat, sangat menarik, sangat praktis. Oleh karena itu hasil penilaian dari ahli media 1 dan 2 secara keseluruhan dapat dimaknai bahwa materi layanan informasi studi lanjut berbantuan media sosial instagram untuk perencanaan karir siswa SMA, yang didesain berupa poster ringkas merupakan media layanan informasi yang sangat berterima, tepat, jelas dan ringkas untuk digunakan oleh siswa untuk menjadi sumber belajar dalam mengeksplor studi lanjutan.

Analisis keseluruhan terhadap hasil penilaian ahli materi yakni sebesar 0,91, maka termasuk dalam kriteria validitas rentang nilai $0,76-1,00$. Hasil penilaian dari ahli materi, secara keseluruhan dapat dimaknai bahwa materi layanan informasi studi lanjut berbantuan media sosial instagram untuk perencanaan karir siswa SMA, yang didesain berupa poster ringkas memiliki validitas yang sangat tepat, sangat bermanfaat, sangat menarik, sangat praktis sehingga keberterimaan produk sebagai media layanan informasi studi lanjut untuk siswa SMA sangat baik.

Analisis keseluruhan terhadap hasil uji calon pengguna (konselor) yakni sebesar 1, maka termasuk dalam kriteria validitas rentang nilai 0,76 - 1,00 Sehingga produk dinilai memiliki kriteria yang sangat tinggi (sangat tepat, sangat bermanfaat, sangat menarik, dan sangat praktis). Sehingga secara keseluruhan, keberterimaan produk sebagai media layanan informasi studi lanjut untuk siswa SMA sangat baik. 


\subsection{Pembahasan}

Produk yang dikembangkan dalam penelitian ini secara sistematis berdasarkan model pengembangan Borg and Gall (1983) yang terdiri dari 10 langkah, yang kemudian dimodifikasi oleh peneliti dan disederhanakan menjadi delapan langkah, mengingat keterbatasan waktu dan tenaga yang dimiliki oleh peneliti. Materi layanan informasi studi lanjut berbantuan media sosial instagram untuk perencanaan karier siswa SMA yang telah dikembangkan, berdasarkan penilaian dari ahli materi, ahli media, serta calon pengguna (konselor) secara umum telah memenuhi kriteria ketentuan.

Materi layanan informasi studi lanjut ini disusun dan dibuat berdasarkan need assessment yang telah dilaksanakan oleh peneliti di SMAN 1 Durenan di Trenggalek. Need assessment dilakukan kepada siswa kelas XI jurusan IPS untuk mengetahui kebutuhan siswa mengenai informasi studi lanjut dan melakukan wawancara kepada konselor SMAN 1 Durenan agar produk bisa tepat sasaran.

Materi layanan informasi studi lanjut, yang dikembangkan terdiri dari 12 materi antara lain: memaparkan berbagai macam informasi studi lanjut, seperti paparan mengenai klasifikasi pendidikan tinggi di Indonesia, macam-macam Perguruan Tinggi, macam-macam Universitas, explore Institut di Indonesia, macam-macam Politeknik, explore sekolah tinggi, mengenal Akademi di Indonesia, tips menghadapi tes seleksi masuk perguruan tinggi, informasi UTBK-SBMPTN, SNMPTN 2021 dan hal-hal yang harus dilakukan ketika memilih studi lanjut. Materi dibuat ringkas, agar pembaca/siswa mampu tertuju langsung pada inti materi. Materi layanan informasi studi lanjut berbantuan media sosial instagram ini mampu diakses oleh siswa kapanpun dan dimanapun tanpa arahan langsung oleh konselor, sehingga mempermudah siswa dalam mengeksplorasi informasi belajar mereka mengenai studi lanjutan. Produk yang dihasilkan kedepannya, setiap bulannya akan selalu ter-update, sesuai dengan informasi studi lanjut yang sedang berkembang saat itu juga.

Produk materi layanan informasi studi lanjut berbantuan media sosial instagram untuk perencanaan karir siswa SMA ini disertai buku panduan untuk konselor yang berperan penting dalam memberikan layanan bimbingan karir. Seperti yang dipaparkan oleh (Munandir, 1996) bahwa layanan bimbingan karier diberikan untuk membantu siswa yang mengalami masalah, khususnya berkenaan dengan penyusunan rencana untuk masa depannya. Buku panduan untuk konselor yang dikembangkan bertujuan membantu konselor dalam melancarkan proses layanan bimbingan karier. Buku panduan berisikan kajian teori, cara mengakses akun @explore_studilanjut pada instagram, RPLBK, serta lampiran evaluasi proses, evaluasi hasil dan panduan tanya jawab.

Produk materi layanan informasi studi lanjut berbantuan media sosial instagram telah tervalidasi oleh 2 ahli media, 2 ahli materi dan 2 calon pengguna (konselor). Penilaian didasarkan pada 4 aspek keberterimaan yakni: ketepatan, kegunaan, kemenarikan, dan kemudahan. Penilaian yang diberikan oleh keempat ahli memiliki relevansi tinggi, yang memiliki validitas sangat tepat, sangat bermanfaat, sangat menarik, sangat praktis sehingga secara umum dapat dikatakan produk dapat digunakan oleh konselor dan siswa.

Produk materi layanan informasi studi lanjut berbantuan media sosial instagram ini dinilai memenuhi aspek ketepatan. Aspek ketepatan dilihat dari penilaian ahli media yakni ketepatan materi, ketepatan pemilihan judul/topik yang terdapat pada materi, ketepatan 
pemilihan animasi, ketepatan pemilihan warna pada poster materi, dan ketepatan desain yang dipilih pada poster. Aspek ketepatan dapat dilihat juga dari penilaian ahli materi yakni ketepatan penggunaan bahasa pada materi, ketepatan topik, serta ketepatan materi layanan informasi studi lanjut.

Produk yang telah melalui tahap revisi dapat dikatakan memiliki kualitas yang baik. Sehingga produk sudah layak untuk diberikan kepada calon pengguna yakni konselor dan siswa SMA. Produk dapat digunakan oleh konselor sebagai media penyampaian layanan informasi studi lanjut kepada siswa melalui layanan klasikal secara luring maupun daring. Sedangkan siswa SMA dapat mengakses produk tersebut untuk memenuhi kebutuhan belajar tentang informasi studi lanjut melalui materi layanan informasi studi lanjut berbantuan media sosial instagram melalui akun instagram@explore_studilanjut.

\section{Simpulan}

Berdasarkan hasil analisis dapat dipaparkan simpulan yang dapat diambil dari pengembangan materi layanan informasi studi lanjut berbantuan media sosial instagram untuk perencanaan karier siswa SMA. (1) Produk yang dikembangkan berupa materi layanan informasi studi lanjut berbantuan media sosial instagram dan buku panduan untuk konselor dalam menggunakan produk pengembangan materi layanan studi lanjut berbantuan media sosial instagram dalam memberikan layanan bimbingan karier di sekolah. (2) Produk materi layanan informasi studi lanjut berbantuan media sosial instagram yang telah memenuhi kriteria akseptabilitas yaitu aspek ketepatan, kemenarikan, kemudahan dan kegunaan yang sangat tinggi dengan kriteria validitas sangat tepat, sangat bermanfaat, sangat menarik dan sangat praktis sehingga produk dapat digunakan untuk mengeksplorasi informasi studi lanjutan oleh siswa dan dapat digunakan oleh konselor dalam memberikan layanan informasi studi lanjut.

\section{Daftar Rujukan}

ABKIN. (2007). Penataan Pendidikan Profesional Konselor dan Layanan bimbingan dan konseling dalam jalur pendidikan formal. Bandung: Asosiasi Bimbingan dan Konseling Indonesia.

Crites, J. O. (1981). Career Counseling; Models, Methods and Material. New York: McGraw-Hill Book Company.

Hidayati, R. (2015). Layanan Informasi Karier Membantu Peserta Didik dalam Meningkatkan Pemahaman Karier. Jurnal konseling GUSJIGANG. 1(1)

Listianah. (2013). Penerapan Layanan Informasi Dengan Menggunakan Media Movie Maker Untuk Meningkatkan Pemahaman Memilih Studi Lanjut Pada Siswa Kelas Xii Di Sma Negeri 3 Lamongan. Jurnal Mahasiswa Bimbingan Konseling. 1(1), 158-165.

Munandir. (1996). Program Bimbingan Karier di Sekolah. Jakarta. Dirjen Dikti.

Nursalim, M. \& Suradi. (2002). Layanan Bimbingan dan Konseling. Jakarta: PT Rineka Cipta.

Noviyanti, N. (2020). Instagram Social Media As Guidance And Counseling Media Based On Technology. International Journal of Applied Guidance Counseling. 1(1), 16-19.

Patton, W. \& Creed, P. (2003). Predicting two Components of career Maturaty in School Based Adolescents. Journal of Career Development. 29 (4), 277-290.

Prayitno \& Eman A. (2004). Dasar-dasar Bimbingan Konseling. Jakarta: Rineka Cipta.

Prayitno. (2012). Jenis Layanan dan Kegiatan Pendukung Konseling. Padang: Program Pendidikan Profesi Konselor Jurusan Bimbingan dan Konseling FIP UNP.

Rusandi, A. \& Liza, L. (2016). Pengaruh Layanan Informasi Tentang Studi Lanjut Terhadap Perencanaan Karir Siswa Kelas XI IPA SMA Negeri 1 Pekanbaru Tahun Ajaran 2013/2014. Jurnal Bimbingan Konseling Indonesia. 1(1). 
Jurnal Pembelajaran, Bimbingan, dan Pengelolaan Pendidikan, 1(5), 2021, 394-400

Sugiyono. (2010). Metode Penelitian Pendidikan Pendekatan Kuantitatif, Kualitatif, $R \& D$. Bandung: Alfabeta. Sugiyono. (2017). Metode Penelitian Kuantitatif, Kualitatif, dan R\&D. Bandung: Alfabeta, CV. 